\title{
Democracy Matters: Giving Students a Political Voice ${ }^{1}$
}

\author{
Joan D. Mandle ${ }^{2}$
}

[Article copies available for a fee from The Transformative Studies Institute. E-mail address: journal@transformativestudies.org Website: http://www.transformativestudies.org (02011 by The Transformative Studies Institute. All rights reserved.]

Since the publication of C. Wright Mills's brilliant Sociological Imagination in 1959, many sociologists have explored the intersection of private troubles (biography) and public issues (social structure) (see Mills, pp. 7-11). My own passion as a sociologist has been similarly focused-on understanding how people attempt to remedy their personal (private) concerns by challenging and changing society's institutions (social structures) through social movements. But, following Marx's (1845/1998) dictum not to just understand but also to change the world, I have actively participated in movements for social change since 1964 when, as an undergraduate, I became part of the civil rights movement's Freedom Summer.

In the movements that followed - the antiwar, student, and antipoverty movements of the 1960s, and later the women's and environmental movements - students connected their private concerns about the draft, discrimination, or the destruction of the natural world with political efforts to change laws. My research followed these movements, tracking

\footnotetext{
${ }^{1}$ Joan Mandle, Sociologists in Action pp. 266-270, copyright 2011 by Pine Forge Press, Reprinted by Permission of Pine Forge Inc.

2 Joan Mandle is the executive director of the national nonpartisan student organization, Democracy Matters, and Professor Emerita of Sociology at Colgate University. She directed the college's Women's Studies Program from 1991-2000 and founded the Colgate Center for Women's Studies. Her teaching and extensive published work exploring social change and social movements include Women and Social Change in America (second edition, 1981), and Can We Wear Our Pearls and Still Be Feminists: Memoirs of a Campus Struggle (2000). She has taught sociology in Japan and China, and has been a Distinguished Visitor at both University of California, Berkeley and Mills College. In 1984 and again in 1986, Professor Mandle was Campaign Manager for incumbent congressman Bob Edgar of Pennsylvania.
} 